description and figures may be gained from the fact that the five parts in all run to 1185 pages and 166 plates. Probably no mycologist, with the exception of Elias Fries, has ever been identified with a group to the extent that Thaxter was with the Laboulbeniaceæ. However, he did not restrict his observations to this fascinating group, but seemed to possess an almost unhuman flair for finding fungi which he himself called "new or peculiar", and described by him occasionally throughout his career. He was, moreover, the first to recognise the anomalous group Myxobacteriaceæ which have lately come into fashion.

Thaxter's association with Prof. W. G. Farlow at Harvard was an ideal one, and together they succeeded in building up a school of cryptogamic botany and herbarium which are without rival in any university. For a number of years Thaxter suffered from ill-health, but his letters were always cheerful, even when increasing trouble with cataract made it seem probable that he would be compelled to cease work. He was somewhat critical of some of the recent tendencies in applied mycology, but his criticisms were given from the fullness of his knowledge of the subject and not from a feeling of having been left behind.

In 1907, Thaxter succeeded Farlow as American editor of the Annals of Botany, Farlow having served since its beginning in 1887 . His name was thus always prominently before British botanists. He received many distinctions; among others, he was a foreign member of the Linnean Society of London, honorary fellow of the Royal Society of Edinburgh, and honorary member of the British Mycological Society.

\section{Dr. Cuthbert Christy}

News has recently been received of the death on May 29, at sixty-eight years of age, of Dr. Cuthbert Christy, the well-known naturalist and explorer, who was engaged in scientific work for the Belgian Government in the Congo. It appears that, while in the Aka River region, he wounded a buffalo which turned and gored him, inflicting fatal injuries. He had for many years been collecting for the British Museum (Natural History), and his collections, notably those from Lakes Nyasa and Tanganyika, have proved to be of quite exceptional importance.

Dr. Christy was the son of Robert Christy of Chelmsford, and was educated at Scarborough and the University of Edinburgh, where he proceeded to take a medical degree and was appointed Mackenzie bursar in anatomy. His first travels abroad started in 1892, when for three years he travelled throughout a large part of South America and the West Indies. Some years later he was appointed Medical Officer of the 2nd Battalion West African Field Force in Northern Nigeria, and afterwards took on the duties of medical officer in India in the Bombay Plague Laboratory. In 1902 he served on the first Sleeping Sickness Commission in Africa, and at a later date was a member of the Liverpool School of Tropical Medicine
Sleeping Sickness Expedition to the Congo, and of that organised by the Sudan Government.

Dr. Christy's intimate knowledge of native life in health and disease, and his explorations in many fields, are revealed to some extent in several published works and reports, among them being "Big Game and Pygmies", "Mosquitoes and Malaria", and "The Birds of San Domingo". He was chairman of the International Commission appointed by the League of Nations to inquire into the existence of slavery and forced labour in Liberia; and the recommendations of the Commission were accepted by the Council of the League and the Liberian Government.

Between 1903 and 1910, Dr. Christy visited Ceylon and various parts of East and West Africa, all the time collecting such specimens for the Natural History Museum as came his way. From 1911 until 1914 he was engaged in scientific exploration work in the Congo, and during this period he obtained many specimens for the Museum collections.

Among the mammals collected during this period were an important collection from the neighbourhood of Avakubi, in which Dr. Christy obtained two rats new to science and a dormouse which was named after him, Graphiurus christyi. He also obtained specimens of many rare West African forms in the same collection, thus adding considerably to our knowledge of the distribution of these species.

During the War, in spite of official duties, Dr. Christy still continued to collect, and sent home a very fine collection of fish from Mesopotamia. After the War he conducted two very important expeditions, one to Lake Nyasa and one to Lake Tanganyika, where he collected a great quantity and variety of fishes. These collections have proved to be some of the most important that have ever been received by the Natural History Museum, and the number of new species already described is very great; in one genus alone the species have been multiplied by six since Dr. Christy's collection has been worked out. The work in connexion with these collections is still continuing and many new forms doubtless remain to be described.

Medical science has lost a very able man in the death of Dr. Christy, and zoological science has lost one of its keenest collectors and most painstaking observers.

\section{Mr. L. G. Sutron}

The death of Mr. Leonard Goodhart Sutton, in his sixty-ninth year, took place somewhat suddenly at his residence, "Hillside", Reading, on June 13. Mr. Sutton was a grandson of the founder, and at the time of his death senior partner, of the worldfamous firm of Sutton and Sons. He was educated at Wellington College, and later went to the Royal Agricultural College, Cirencester, where he became particularly interested in the botany of grasses, of which group of plants he had a wide and accurate knowledge. After leaving Cirencester, Mr. Sutton spent two years in Germany, devoting himself to the study of the methods of seed production. On returning to England he entered the firm as a

$$
\text { No. 3272, VoL. 130] }
$$

